УДК 373.5.016:511.12

DOI https://doi.org/10.26661/2522-4360-2021-2-04

\title{
ПОПЕРЕДЖЕННЯ ПОМИЛОК УЧНІВ ПІД ЧАС ВИВЧЕННЯ ТЕМИ «ЦІЛІ ВИРАЗИ»
}

\author{
Благодир Л. А. \\ кандидат педагогічних наук, \\ доцент кафедри вищої математики та методики навчання математики \\ Уманський державний педагогічний університет імені Павла Тичини \\ вул. Садова, 2, Умань, Черкаська область, Украӥна \\ orcid.org/0000-0003-3730-6049 \\ blagodirla@gmail.com
}

Ключові слова: методичні прийоми, базова середня освіта, алгебра, типові помилки, превентивна діяльність
Серед змістових ліній шкільного курсу алгебри суттєво значущою $\epsilon$ лінія виразів та їх перетворень. Вільне виконання основних видів перетворень цілих і дробових, раціональних та ірраціональних виразів $€$ передумовою подальшого успішного засвоєння інших змістових ліній. Тому забезпечення міцних знань і вмінь щодо тотожних перетворень виразів має стати предметом постійної уваги вчителя математики.

У статті розглядаються типові помилки учнів під час вивчення змістової лінії виразів та перетворення виразів курсу алгебри в закладах, що забезпечують базову середню освіту, а саме у процесі вивчення теми «Цілі вирази». Здійснюється аналіз найпоширеніших математичних помилок школярів, психолого-педагогічних передумов їх появи. Пропонується методика організації превентивної діяльності вчителя математики (під превентивною діяльністю вчителя математики розуміємо діяльність, яка ініціюється необхідністю попередити математичні помилки учнів, виправити допущені, з’ясувавши причини їх появи, та дібрати раціональні методи, форми роботи і засоби навчання) під час вивчення цілих виразів та перетворень цілих виразів.

Превентивна діяльність має організовуватися як процес взаємодії вчителя і здобувачів освіти, під час якої через спеціально дібрані методи, по-перше, виявляється походження помилок, а по-друге, організовується робота 3 їх попередження та виправлення. Головним завданням формування превентивної діяльності здобувачів освіти є розвиток у них вміння самостійно дотримуватися всіх ії структурних компонентів.

Результат здійснення такої діяльності значною мірою залежить від того, наскільки вчитель розуміє структуру психічної діяльності школярів у конкретних умовах навчання, уміє врахувати об'єктивні закономірності засвоєння навчального матеріалу, психолого-педагогічні закономірності сприймання та запам'ятовування.

Ефективність запропонованої методики перевірена автором у процесі дослідження: «Методична система аналізу та запобігання математичним помилкам у процесі вивчення алгебри в основній школі». 


\title{
PREVENTION OF STUDENTS MISTAKES WHILE STUDYING THE TOPIC "WHOLE EXPRESSIONS"
}

\author{
Blagodyr L. A. \\ Candidate of Pedagogical Sciences, \\ Associate Professor at the Department of Higher Mathematics and Methods \\ of Teaching Mathematics \\ Uman State Pedagogical University named after Pavel Tychyna \\ Sadova str., 2, Uman, Cherkasy region, Ukraine \\ orcid.org/0000-0003-3730-6049 \\ blagodirla@gmail.com
}

Key words: methodical receptions, basic secondary education, algebra, typical mistakes, preventive activity.

\begin{abstract}
Among the semantic lines of the school course of algebra, the line of expressions and their transformations is essentially significant. Free execution of the main types of transformations of whole and fractional, rational and irrational expressions is a prerequisite for further successful mastering of other semantic lines. Therefore, the provision of strong knowledge and skills on identical transformations of expressions should be the subject of constant attention of the mathematics teacher.

The article considers typical mistakes of students during the study of the semantic line of expression and transformation of expressions, the course of algebra in institutions that provide basic secondary education, namely in the process of studying the topic "Whole expressions". The analysis of the most widespread mathematical errors of schoolboys, psychological and pedagogical preconditions of their occurrence is carried out. The method of organization of preventive activity of the teacher of mathematics is offered (under preventive activity of the teacher of mathematics we understand activity which is initiated by necessity: to prevent mathematical mistakes of pupils, to correct the admitted, having found out the reasons of their occurrence and to choose rational methods and transformations of whole expressions.

Preventive activities should be organized as a process of interaction between teachers and students, during which through specially selected methods, firstly, reveals the origin of errors, and secondly, organizes work to prevent and correct them. The main task of the formation of preventive activities of students is to develop their ability to independently adhere to all its structural components. The result of such activities largely depends on how the teacher understands the structure of mental activity of students in specific learning conditions, is able to take into account the objective patterns of learning material, psychological and pedagogical patterns of perception and memory.

The effectiveness of the proposed method was tested by the author in the research process: "Methodical system of analysis and prevention of mathematical errors in the study of algebra in primary school".
\end{abstract}

Постановка проблеми. Математика завжди вважалася і вважається одним із найскладніших шкільних навчальних предметів. В останні роки знижується інтерес до вивчення цього предмета, зокрема до вивчення алгебри в базовій школі. Вивчаючи іiі, учні допускають багато помилок. Забезпеченню якісної математичної підготовки сприяє робота із запобігання, виявлення та виправлення таких помилок у знаннях та вміннях учнів.

Щоб успішно навчати учнів, кожен учитель повинен знати не тільки те, чому навчати учнів, а й як навчати: знати різні методи формування понять, доведень теорем, розв'язування задач; знати переваги i недоліки кожного методу навчання, уміти передбачати, як той чи інший iз них сприяє успішному навчанню учнів; які помилки вони допускають під час вивчення певної змістової лінії; вміти вчасно допомагати учням самостійно знаходити помилки, усувати їх, запобігати появі інших.

У науково-методичній літературі пропонуються різні шляхи вдосконалення освітнього процесу, 
використовуються нові методики та сучасні технології навчання, однак аналіз практики навчання математики, результати ДПА та ЗНО свідчать про те, що робота над помилками учнів $є$ проблемною зоною в організації освітньої діяльності. Удосконалення програм і методів навчання, нові підручники, як свідчить практика, не викорінюють автоматично математичні помилки учнів. Ось чому ця проблема 1 на сучасному етапі розвитку освіти потребує належної уваги методистів та педагогів-практиків. Важливе значення має попередження помилок учнів, діяльність, яка має грунтуватися на знаннях учителем особливостей засвоєння учнями навчального матеріалу, змісту типових помилок, яких припускаються учні, розумінні причин їх появи. Методичні особливості організації превентивної діяльності сучасного вчителя математики, яка спрямована на попередження появи можливих математичних помилок учнів, здійснення аналізу та виправлення допущених помилок, визначено в роботах $[1,2]$.

Аналіз актуальних досліджень. Проблема виявлення та виправлення математичних помилок учнів знаходить своє відображення у працях вчених-математиків, психологів і педагогів протягом усієї історії розвитку математичної освіти. Зокрема, в роботах Г.П. Бевза, В.О. Далінгера, O.С. Дубинчук, I.М. Кирилецького, Л.М. Литвиненко, Н.О. Менчинської, 3.І. Слєпкань, О.А. Тарасової, Л.П. Черкаської П.О. Шеварьова та інших.

Однак помилки, яких припускаються учні, продовжують 3'являтися i бути проблемною зоною на шляху успішного навчання. На нашу думку, однією із причин появи помилок є певні недоліки у самій організації освітнього процесу.

Мета статті - розглянути типові помилки учнів, розкрити причини їх виникнення та запропонувати методичні прийоми організації діяльності з їх попередження час вивчення цілих виразів та перетворень таких виразів.

\section{Виклад основного матеріалу.}

За результатами проведення великої кількості контрольних зрізів (констатувальний експеримент дисертаційної роботи), анкетувань учителів математики, аналізу відповідної методичної літератури, упорядкування та осмислення власного досвіду нами були встановлені емпіричним шляхом такі найпоширеніші помилки учнів під час вивчення теми «Цілі вирази» і причини їх появи:

Під час піднесення до степеня одночлена учні:

- коефіиіснт основи степеня множать на показник степеня: $\left(2 x^{2} y^{2}\right)^{3}=6 x^{6} y^{6}$. Причиною такої помилки є неправильна аналогія дії піднесення до степеня $з$ дією множення (інтерференція);

- підносять до степеня тільки коефіиієнт основи: $\quad\left(6 m^{2} n\right)^{2}=36 m^{2} n$. Причиною появи цієї помилки $\epsilon$ перенесення знань щодо множення одночлена на число та незнання правила піднесення до степеня добутку;
- коефіиіснт основи не підносять до степеня, наприклад: $\left(3 x^{2} y^{3}\right)^{3}=3 x^{6} y^{9}$. Причина в тому, що під час множення одночленів сформувалася помилкова асоціація. Тому під час піднесення до степеня учні підносять лише один із множників, а в кращому разі всю буквену частину одночлена. Якщо не викорінити та не попередити появу таких помилок, вони можуть з'являтися під час піднесення ірраціональних виразів до степеня та розв'язування ірраціональних рівнянь;

- показники степенів додають або підносять до степеня, наприклад: $\left(x^{3} y^{2}\right)^{2}=x^{5} y^{4} ;\left(2 a^{2} b^{3}\right)^{2}=4 a^{4} b^{9}$. Такі помилки $є$ наслідком поверхового знання правил піднесення до степеня добутку і правил піднесення степеня до степеня.

Досить часто учні порушують правило розкриття дужок, особливо якщо перед дужкою стоїть знак «мінус», наприклад: $(5 x-1)-(-1+3 x)=5 x-1+1+3 x=8 x$. Причиною таких помилок $€$ формально завчені правила розкриття дужок та нераціонально дібрана вчителем система вправ на осмислення та закріплення правил.

Типовими $є$ помилки, які виникають під час множення многочлена на одночлен: $c(2 x+b)=2 x c+b ;(a+b-c) \cdot 4 a^{2}=a+b-4 a^{2} c$.

Розкриваючи дужки, учні множать на одночлен тільки той член многочлена, який знаходиться в дужках першим. Це свідчить про те, що вивчення розподільної властивості множення відносно додавання відбулося на формальному рівні.

Розповсюдженою помилкою є втрата знаків коефіцієнтів алгебраїчних виразів. Часто учні вважають, що коефіцієнти одночленів $a^{2} c ;-b c^{2}$ дорівнюють нулю. Причиною $є$ несформовані вміння учнів визначати коефіцієнт одночлена. Зокрема, втрата 3 поля зору знаку коефіцієнта призводить до помилок у діях над одночленами i многочленами, а в подальшому - в розв'язуванні лінійних та квадратних рівнянь.

Значною кількістю помилок супроводжується зведення подібних доданків, зокрема учні:

- коефіцієнти додають, а буквені вирази знищують, наприклад: Ошибка! Объект не может быть создан из кодов полей редактирования.;

- додають $і$ коефіuуінти і показники степенів, наприклад $3 x^{2}+2 x^{6}=5 x^{8} ; 15 y^{5}-3 y^{4}=12 \mathrm{y}$;

- коефіиієнти додають, а буквені вирази перемножують, наприклад: $4 x+7 x=11 x^{2}$.

Причиною таких помилок $є$ те, що учні не усвідомили поняття змінної, не розуміють, що замість букв можна підставляти будь-які числа, а тому зводять подібні доданки несвідомо.

Під час множення одночленів учні:

- знаходять добуток тільки коефіuієнтів, наприклад: $12 x^{2} y 7 x^{2} y=84 x^{2} y$; 
- множать кожен коефічієнт окремо, наприклад: $3 c^{2} b \cdot 4 c a \cdot 2 b=12 \cdot 6 c^{3} b^{2} a=72 c^{3} b^{2} a$;

- перемножують показники степенів, наприклад: $x^{2} y^{4} \cdot 4 x^{2} y^{2}=4 x^{4} y^{8}$;

- під час піднесення одночлена до степеня знаходять добуток коефіиієнта на показник степеня; показники степенів додають: $\left(3 a^{2} b^{4}\right)^{2}=6 a^{4} b^{8}$;

- під час множення многочленів не використовують розподільну властивість множення, наприклад: $(2 a+3 b)(4 c+5 a)=8 a c+15 a b$.

Помилки $(a \pm b)^{2}=a^{2} \pm b^{2} ;(a \pm b)^{3}=a^{3} \pm b^{3}$ з'являються, якщо під час піднесення до степеня многочлена використовується хибна розподільна властивість. Помилкова асоціація, яка сформувалася під час вивчення розподільної властивості множення відносно додавання, сприяла неправильній аналогії. Причиною таких помилок $є$ зовнішня схожість виразів $(a+b) \cdot 2$ та $(a+b){ }^{2}$

3 метою попередження таких помилок, які досить часто з'являються під час вивчення формул скороченого множення та у подальшому використанні цих формул, доцільно під час множення многочленів розглянути завдання на піднесення двочленів до другого та третього степенів. Звернути увагу учнів на те, що кількість членів результату до зведення подібних буде $2^{n}$, а після зведення подібних завжди буде більше показника степеня двочлена на один. Такий попередній підрахунок викликає інтерес і є певним засобом стійкого засвоєння формул.

Розкладаючи многочлени на множники, учні:

- втрачають один під час винесення спільного множника за дужки, наприклад: $8 x^{3}+4 x^{2}-2 x=2 x\left(4 x^{2}+2 x\right)$. Причиною с не відпраиььований алгоритм винесення спільного множника за дужки і нерозуміння того, шчо результатом ділення виразу самого на себе є один;

- не завжди доводять перетворення до кіния, наприклад: $x^{4}-y^{4}=\left(x^{2}-y^{2}\right)\left(x^{2}+y^{2}\right)$;

- помиляються $y$ знаках під час винесення за дужки від'ємного множника, наприклад: $a c-b c-a^{2}+2 a b-b^{2}=a c-b c-\left(a^{2}+2 a b-b^{2}\right), \quad$ щзо $\epsilon$ наслідком несформованих умінь розкривати дужки та у разі необхідності брати вирази в дужки;

- допускають помилки у завданнях на використання формул, наприклад:

б) $a^{3}-b^{3}=(a-b)(a-b)(a-b)$; a) $a^{2}-b^{2}=(a-b)(a-b)$

в) $a^{3}+b^{3}=(a+b)\left(a^{2}+b^{2}\right)$

2) $\left.a^{2}+b^{2}=(a+b)(a+b) ; \partial\right)(a+b)^{2}=a^{2}+b^{2}$.

Враховуючи специфіку вивчення алгебри, зокрема те, що рівень вивчення кожної наступної теми певної змістової лінії прямо залежить від рівня засвоєння вивченого навчального матеріалу на попередньому етапі, пояснення нового матеріалу слід будувати на основі повторення, узагаль- нення і систематизаиії відомого. Зокрема, поширеною є помилка у нерозмежуванні виразів «сума квадратів» $\mathrm{i}$ «квадрат суми». Учні швидко запам’ятовують, що в обох виразах спільними є слова «квадрат» і «сума», що і призводить до помилки.

Часто учні допускають помилку $a-b=b-a$, щзо стає у подальшому причиною помилок у зведенні до спільного знаменника раџіональних дробів. Тому щзе на етапі вивчення правил розкриття дужок необхідно планувати діяльність так, щуоб учні иілком свідомо $i$ безпомилково виконували перетворення: $a-b=-(b-a)$.

Труднощі виникають: у виділенні спільного множника в запису многочлена та обчисленні показників степеня членів многочлена, які залишаються в дужках після винесення спільного множника за дужки; виділенні формули скороченого множення в цьому многочлені, наприклад: $4 a^{2}-6 a b+9 b^{2}=(2 a-3 b)^{2}$. Причиною появи таких помилок $є$ порушення принципу повноти в системі тренувальних вправ.

Здійснюючи аналіз помилок, вчителю необхідно з'ясувати, які умови забезпечать правильне виконання завдання і які чинники можуть викликати його помилкове виконання.

Виходячи 3 асоціативно-рефлекторної теорії П.О. Шеварьова [3], учень може зробити помилкову дію у двох ситуаціях: якщо в нього актуалізується правильний ланцюг асоціацій, але актуалізується не повністю, відсутня певна ланка, або якщо в учня актуалізується помилкова асоціація. Завдання вчителя у першому разі - перевірити склад і міцність усіх ланок у правильному ланцюгу асоціацій, у другому - виявити помилкову асоціацію, що актуалізувалась у мисленні учня, та замінити правильною асоціацією.

Відомо, що якщо дві події відбуваються близько в часі чи просторі, то на основі сформованого зв'язку у людському мисленні під час настання однієї $з$ них людина очікує другої. Так і під час розв' язування математичних задач: якщо із суб'єктивного погляду конкретна задача чи іiі частина здається учню схожою до розв'язаної раніше, то він переносить елементи відомої задачі на нову, не помічаючи суттєвої відмінності між ними.

Враховуючи специфіку вивчення алгебри, зокрема те, що рівень вивчення кожної наступної теми певної змістової лінії прямо залежить від рівня засвоєння вивченого навчального матеріалу на попередньому етапі, пояснення нового матеріалу слід будувати на основі повторення, узагальнення і систематизації відомого, необхідно здійснювати постійний зв'язок між вивченим і новим.

У процесі вивчення нових понять (тверджень) корисно пов'язувати їх з уже відомими, визначати загальні суттєві ознаки в характеристиці нових i відомих понять. 
Помилки з’ являються ще й тому, що математика вимагає чіткості означень, послідовності міркувань, правильності висновків. А учні намагаються охопити навчальний матеріал лише пам'яттю. Тому вчителю треба зменшити використання таких форм роботи, коли знання передаються в готовому вигляді. Потрібно, щоб матеріал вивчався під час напруженої розумової діяльності. Перш ніж сказати «тому що» або «звідси», треба, щоби в учнів виникло запитання «чому?» або «звідки?». Розглянемо детальніше найпоширеніші помилки учнів у процесі вивчення теми «Одночлени».

Як показало наше експериментальне дослідження, значну кількість помилок школярі допускають під час запису одночлена у стандартному вигляді та у виконанні дій додавання та множення одночленів. Причиною появи таких помилок є недостатньо сформоване поняття степеня та невміння правильно застосовувати властивості степенів.

Так, виконуючи тотожні перетворення виразів, учні не розмежовують дії добутку степенів та піднесення степеня до степеня, допускають помилку: $\left(a^{m}\right)^{n}=a^{m+n}(*)$

Практика показує, що з метою попередження такої помилки під час вивчення властивостей: $a^{m} \cdot a^{n}=a^{m+n}, m, n \in N ; \quad\left(a^{m}\right)^{n}=a^{m \cdot n}, m, n \in N$ необхідно закріпити в пам'яті учнів особливості Цих виразів, вказавши на спільне та відмінне в них.

Згідно з дослідженням П.О. Шеварьова [3], причиною появи помилки (*) є зовнішня схожість виразів $a^{m} a^{n} \mathrm{i}, m, n \in N$ і помилковий асоціативний зв'язок, який сформувався під час вивчення властивості $a^{m} \cdot a^{n}=a^{m+n} ; m, n \in N$. Тому 3 метою попередження помилки $\left(a^{m}\right)^{n}=a^{m+n}, m, n \in N$ ще на етапі засвоєння властивості $a^{m} \cdot a^{n}=a^{m+n} ; m, n \in N$, необхідно звернути увагу учнів на специфічну особливість формули $a^{m} \cdot a^{n}=a^{m+n} ; m, n \in N$ тобто на те, що між степенями - дія множення, а в результаті показники степенів додаються.

Більшого ефекту можна досягти, працюючи фронтально із класом та залучаючи всіх учнів.
Школярі повинні самі виділити згадану вище особливість, проговорити ऑiі та підкріпити прикладами.

Необхідно відзначити, що у підручниках $\epsilon$ достатня кількість завдань на закріплення властивості $a^{m} \cdot a^{n}=a^{m+n} ; m, n \in N$, що сприяє їі стійкому запам'ятовуванню.

Після уведення властивості $\left(a^{m}\right)^{n}=a^{m \cdot n} ; m, n \in N$, доцільно також проаналізувати 3 учнями особливості цієї рівності, зокрема наявність дужск, показника степеня за дуюками, добутку показників степенів у правій частині рівності.

Наступний етап - порівняння обох вивчених властивостей. Учні повинні або самі, або за підтримки вчителя виділити, що спільного та відмінного вони помітили, сутmєві особливості обов'язково зафіксувати в зошитах чи спеціально відведених довідниках.

Як відомо $з$ досліджень психологів, 80\% інформації людина отримує через зоровий аналізатор. Для попередження математичних помилок учнів ми пропонуємо максимально використовувати візуалізацію навчального матеріалу, що забезпечить цілеспрямовану концентрацію уваги учнів на правильних діях, виділенні спільного і відмінного в формулах (особливо в місцях, де найчастіше виникають труднощі в учнів) під час вивчення нового матеріалу. Засобами візуалізації можуть бути опорні схеми, карти знань, піктограми.

Висновки. У статті розглянуто типові математичні помилки здобувачів освіти, які вони допускають в самостійних, контрольних роботах і під час складання державної підсумкової атестації. Розкрито психолого-педагогічні причини виникнення помилок. Запропоновано методичні прийоми організації діяльності 3 попередження типових помилок під час вивчення цілих виразів та перетворень таких виразів.

Подальших досліджень потребує організація превентивної діяльності вчителя математики під час вивчення дробових раціональних виразів.

\section{ЛIТЕРАТУРА}

1. Благодир Л.А. Превентивна діяльність під час навчання школярів математики. Математика в рідній школі. 2014. № 2. С. 16-20.

2. Швець В.О., Благодир Л. А. Формування вмінь і навичок превентивної діяльності майбутнього вчителя математики. Вища освіта Украӥни №3 (46). 2012. Т. 2. С. 38-46.

3. Шеварев П.А. Опыт психологического анализа алгебраических ошибок. Известия АПН РСФСР, 1946. № 3. C. 135-180.

\section{REFERENCES}

1. Blahodyr L.A. (2014) Preventyvna diialnist pid chas navchannia shkoliariv matematyky [Preventive activity during the teaching of mathematics to students]. Matematyka v ridnii shkoli. № 2. P. 16-20.

2. Shvets V.O., Blahodyr L.A. (2012) Formuvannia vmin i navychok preventyvnoi diialnosti maibutnoho vchytelia matematyky [Formation of skills and abilities of preventive activity of the future teacher of mathematics]. Vyshcha osvita Ukrainy № 3 (46). T. 2. P. 38-46.

3. Hevarev P.A. (1946) Opyt psihologicheskogo analiza algebraicheskih oshibok [Experience of psychological analysis of algebraic errors]. Izvestiya APN RSFSR, № 3. P. 135-180. 